\title{
1. The changing notions of materialism and status in an increasingly dematerialized world
}

\author{
Russell Belk
}

\section{THE DIGITAL WORLD}

One of the first things we do each morning - for some of us even before we get out of bed - is to check how our digital self is doing. What messages have we received on WhatsApp or WeChat? Who has tagged us in photos on Facebook? [What are those whose tweets we are] following saying? What is [the weather today?] How is our bank account doing? Who has shown an interest in our dating profile? How does our Fitbit or Apple Watch say we have slept? Rather than directly taking stock of our body to see how we are doing, we increasingly turn to our digital devices to see how we are. More accurately, we seek to find out how our digital doppelgänger is doing (Bode and Kristensen 2016).

This estranged other or second self is our digital self, a self that is increasingly displacing our corporeal flesh and blood self in terms of its importance in our lives. Our avatars, selfies, and social media profiles are also who we are to those we encounter online. We would rather communicate through these doppelgängers than face-to-face, sometimes even when we are in the same room with someone. And we increasingly talk to Artificial Intelligence (AI) digital assistants in our homes, vehicles, and phones. We get our news, music, films, and messages through our digital devices. We feel naked without these extensions of self (Belk 2013). Our world is becoming more and more digital. And with digitization and the internet, we may well feel more anonymous, invisible, fanciful, and even imaginary. On the other hand, we may feel under constant surveillance, a lack of privacy, and a sense of vulnerability.

Besides the changes the digital world has made in our notions and representations of self, it has also changed the nature of possessions. In many cases once-material objects have dematerialized. Books, magazines, letters, musical and film recordings, photographs, data, money, greeting cards, clocks, calendars, newspapers, travel agents, ticket agents, typewriters, translators, libraries, retail stores, banks, offices, and many other physical things have disappeared and been replaced by non-material digital equivalents, improvements, and innovations.

With this dematerialization, some of the qualities that made certain objects luxuries, collectible, and valuable have also disappeared. Chief among these qualities are scarcity, uniqueness, and permanence. With the ease of digital duplication, the speed of digital online access, and the decline or disappearance of monetary cost for many 
of these things, our ideas of rarity and value have changed. Once-enduring things like love letters have become more ephemeral. A rare recording of an opera performance or a limited-edition book are now freely available with a few strokes of our laptop keyboard. We don't have to haunt small clubs to become knowledgeable about the latest music; musicians upload performances to YouTube for anyone to access.

These digital changes have upset many industries and resulted in some fundamental restructuring. Many new opportunities have also emerged in marketing digital goods and services. Cleverness and adaptability have often been required to adapt to the dematerialization of once scarce goods. For example, Topps originally sold physical sports trading cards that were offered in packs of five cards with a piece of chewing gum. New cards came out each season and had the player's photo on the front and statistics on the back. Enthusiasts collected the cards and rare cards of famous players commanded high prices in the collector aftermarket. Now with photos and stats instantly available online, there doesn't seem to be much call for the cards any longer. But Topps succeeded in introducing digital cards that buyers could keep online as well as trade or sell to others. They also introduced unique features like stats that change as games are played, mystery packs in which it is uncertain which cards will appear, and limited editions and cards that are only available during limited time periods. These innovative adaptations have resulted in a \$330 million market for Topps virtual cards (Mardon and Belk 2018).

\section{THE SHARING ECONOMY AND NON-OWNERSHIP}

In addition to digitization, a second factor that has helped to de-materialize consumption recently is the rise of the so-called sharing economy. Simply put, when we share things, we don't need to own them and fewer of these things are needed, whether they are cars, rides, clothing, children's toys, or adult tools. While we have long shared things with family and friends (Gibson et al. 2018; Widlok 2017), the internet and digital devices have facilitated sharing with strangers as well as commercial "sharing" (Belk 2010; 2014b). Rather than true sharing, most of these commercial ventures are more aptly described as short-term rental (Bardhi and Eckhardt 2015; Belk 2014a). This still results in less consumption, but it lacks the caring involvement of those participating in true sharing without purely economic motivations (Bardhi and Eckhardt 2012; Belk 2017c).

Both true sharing and the pseudo-sharing of short-term rental suggest that the importance of ownership of consumer goods may be declining (Belk 2015; Eckhardt and Bardhi 2016; Rudmin 2016). It is possible that the generation that has grown up digital (Palfrey and Gasser 2008; Tapscott 2008) is less enthralled with owning goods ranging from clothes and music to homes and vehicles. Although Topps may have found ways to make virtual goods collectible, even the lure of owning and collecting art may be declining (Chen 2009). On the other hand, those who are more materialistic are less likely to share with others (Belk 2017b) as well as more likely to prefer tangible goods rather than their digital equivalents (Lewis and Moital 2016). 
In a large-scale anonymous city where people may not even know their neighbors (Putnam 2000), renting or leasing expensive, high-status items may be a way to leverage our lifestyles by renting rather than purchasing what would otherwise be unaffordable consumer luxury goods. For a moderate monthly subscription fee, Bag, Borrow or Steal allows consumers to borrow designer handbags, watches, jewelry, evening dresses, coats, sunglasses, and more. As soon as one is returned another can be borrowed, suggesting to strangers and casual acquaintances that the consumer has a large wardrobe of luxuries. Other short-term rental firms with names like Rent the Runway, Luxus Babe, Girl Meets Dress, Chic by Choice, and Erento do something similar. For profit and non-profit fashion libraries offer another variant of these services. They allow members to check out fashion clothing as they might check out a book at a public library (Pedersen and Netter 2015). See Chapter 2 in this volume for further examples.

But while the rental market is booming (Durgee and O'Connor 1995; Knox and Eliashberg 2008; Moeller and Wittkowski 2010), so is the rental of storage space in order to store the possessions that overflow from our households (Arnold et al. 2012), suggesting that it is far too early to conclude that the sharing economy is replacing the ownership economy. The reasons may lie in the types of property rights that inhere in outright ownership. According to Furubotn and Pejovich (1972) full ownership in a capitalist society grants four rights:

1. The right to use the good (ius usus).

2. The right to retain the return provided by the use of the good (ius usus fructus).

3. The right to convert the form and structure of the good (ius abusus).

4. The right to transfer any of these property rights to other persons (ius abulendi).

When the good is rented rather than owned, the renter generally only enjoys the first two of these property rights and only for a period of time and under the conditions specified in a rental agreement. But even beyond these truncated rights, the renter knows that they really do not and probably could not afford to own the good outright. For certain digital and virtual goods, the consumer may also be prevented from making duplicate copies of the good to give or sell to others. And although in the early days of the internet the cry was "information wants to be free," the introduction of digital rights management restrictions in digital goods, prosecution of software, music, and film "pirates," and the shutting down of free services like Napster, largely curtailed such idealism (Giesler 2006). There are still open source software platforms like Linux and some free information sources like Wikipedia, but they are the exception rather than the rule. "Free" search engines like Google and "free" social media platforms like Facebook, extract a price in user information that is sold or used to match paying advertisers with potential customers. Access to such services is available to anyone who is willing to sign an End User License Agreement (EULA), trading their privacy for access. Thus, there is no uniqueness, status or conspicuous consumption displayed through such access. 


\section{HAS ALL THAT IS SOLID MELTED INTO THIN AIR?}

Although thanks to digitization, the internet and the sharing economy many consumer goods have dematerialized, it is hardly the case that most consumer goods have become non-material. Most of our food, clothing, furnishings and vehicles are still individually owned and quite material, in both the more affluent and less affluent world. In addition, the proliferation of the digital has also led to a proliferation of new digital devices in order to acquire or access such content (Magaudda 2011; 2012). And both because of rapid innovation in these devices and accessories and because of the status cachet of having the latest thing, there is a rapid turn-over in which consumers replace perfectly functional mobile phones, tablets, laptops and smart watches in order to keep current. It might be thought that this digital keeping up with the Joneses is a phenomenon that is limited to the more affluent world. But this is not the case. Poorer consumers often sacrifice "necessities" like food in order to afford "luxuries" like electronics, entertainment and fashions. This has been called "leaping luxuries," inasmuch as it circumvents "lower order" needs of Maslow's need hierarchy in order to purchase goods satisfying "higher order" needs (Belk 1999). Even though more affluent observers criticize such expenditures and suggest that the poor should instead prioritize nutrition, health care and education, such deferred gratification logic pales in comparison to the lure of a television, smartphones or the latest footwear. Another effect of the internet and global information is that the consumer desiderata of wealthier consumers rapidly transform from luxuries to decencies for those who, according to some sober logic, cannot afford them. For example, in a poor village in rural India most households now have smartphones, even though many lack the literacy and numeracy to be able to use them to connect to the internet (Tenhunen 2018). But this may not be as wasteful as it first appears. Businesses have sprung up that will download music, films, and ringtones for those who cannot do it themselves.

At the same time, new bases for seeking status and luxury have also emerged in the dematerialized world of digital and virtual consumption. For example, in the world of online gaming and virtual economies Lehdonvirta and Castronova (2014) find that rather than a money aristocracy in which those with the most money acquire the highest status positions, there is instead a time aristocracy in which those who invest the most time acquire these positions as well as high-status virtual objects. One result is that those who are younger, without jobs and with more free time rise to positions of prestige and virtual power. Another result is that those who have more money but less free time may hire Chinese "gold miners" to play for them and advance them to higher positions (Wang et al. 2009).

Another effect of time scarcity among two-worker households and the more affluent is the purchase of time-saving services such as dry cleaning, household help, yard care, child care, pet care and food preparation. While it might be thought that these are privileges that only the rich can afford, it is a mark of middle class status in India and other less affluent nations to have one or more servants. As we outsource more and more of our personal lives (Hochschild 2012) and as the middle class in urban 
Asia and South America move into smaller high-rise apartments, the servant class has also begun to view their work as a job rather than a career. It was once the case that wealthier families in West Bengal in India had large homes and servants lived with them for a lifetime. Now the servants are apt to live separately, work part-time for several different employers, and demand benefits (Ray and Qayum 2009). In the process the moral economy and personal relationships of the past give way to the market economy and commodified relationships of the present. This is not only the case in countries where labor is cheap, but also in expensive cities like New York and London.

A further effect of affluence, finite storage, and perhaps sated material desires is a shift among some consumers to lesser materialism, as displayed in an increased interest in acquiring experiences rather than material goods (Pine and Gilmore 1999; Rifkin 2000). Of the three main ways of defining the self - through what we have, what we do, and who we are in some inner sense (Belk 1988), in affluent societies "doing" trumps "having" in terms of contributing to our pursuit of happiness and well-being, especially among Millennials (Kumar et al. 2014; Usborne 2017; Van Boven and Gilovich 2003). This includes holiday vacations, entertainments, restaurant meals, participant sports, and throwing parties. Of course, there may still be a material (or at least digital) counterpart to these experiences when we post photos of us enjoying them on Instagram or Facebook. These are a way of showing off to others that we are doing interesting and exciting things. This in turn suggests that having social experiences and friends with whom we can share them is also an important source of satisfaction. And if we get likes, pokes, and tags online as a result, this can be an important source of self-validation. But it also requires more of our time to keep providing new online material to which others will respond.

One further indicant of a decline in traditional realms of conspicuous consumption of the sort theorized by Veblen $(1899 / 1973)$ and Mason $(1981 ; 1998)$, is the rise of inconspicuous consumption (Chapter 2 in this volume; Berger and Ward 2010; Eckhardt et al. 2015). One factor in such a shift may be the growing disparity in wealth in most world societies. When a person is secure in their class status, there is no need to signal wealth to those far below them (Daloz 2013). This is most likely when class structure is stable or becoming more entrenched. However, Ger and Belk (1999) found that materialism and status display increased in times of instability in class structure, as occurred for example with the fall of Eastern European communism and the re-unification of East and West Germany. We can also see it in China's rapid increase in wealth in recent years (for example, Lu 2008). Another factor prompting a rise in inconspicuous consumption is the shift described above in moving from having to doing. The coffee connoisseur, the oenophile, and the gourmet may sometimes be interested in signaling their elite tastes and possible snobbishness to others, but they are increasingly interested in enjoying the sensory aspects of their consumption experiences (Le Bel 2005; Quintão et al. 2017). By displaying more subtle preferences they may signal their tastes, but these messages are directed primarily to other aficionados as well as others within their social class. The ability to read such subtle signals is in fact a marker of shared class status. With the growth of 
counterfeits, the sharing economy, "democratized luxury," and cheaper versions of luxury brand labels (Danziger 2005; Lin 2011; Silverstein and Fiske 2003; Thomas 2007), inconspicuous luxuries are also a way to employ a code that is more difficult for nouveaux riches and aspiring middle class consumers to recognize, decode, and imitate. While there are other factors driving the move to less conspicuous luxury (Eckhardt et al. 2015), these are thought to be the major forces.

\section{CULTURAL AND TEMPORAL DIFFERENCES}

Although one provocative view suggests that class comparisons and conflicts have been replaced by identity politics and divisions based on race, gender, and lifestyle (Pakulski and Waters 1996), it is more widely thought that class distinctions are alive and well, although they are changing in nature as well as variable across cultures (for example, Currid-Halkett 2017; Daloz 2013; Dickey 2016). One view popularized by Bourdieu (1984) and extended by others such as Holt (1998) is that status is not so much marked by what we own as by what we know by virtue of the habitus in which we were raised and which we have gained through education and experiences. In a contemporary American context, Currid-Halkett (2017) shows that for the aspirational classes this includes knowledge and practices of all that is organic, sustainable, local, renewable, artisanal, and boutique. Potter (2010) mocks these pretenses as embodying an insincere attitude of "greener than thou."

The importance of tangible versus intangible goods to mark status also differs historically and culturally, as Dickey (2016: 17) notes in India: "An intangible good such as honor or respect can affect, for example, access to credit and the terms of repayment, the ability to join a cooperative savings organization or commodities-purchasing group or marriage prospects for children."

Also, high among the other salient status intangibles in India are skin color and caste. Even though discrimination based on caste has been officially outlawed, it has hardly disappeared. The same is true of dowry payments which, if anything, have become more significant in the liberalized Indian economy starting in the early 1990s. Class differences in India, quite apart from caste, are well entrenched and very difficult to overcome. As noted earlier, the servant class is no longer bound by life-long employment by a single family, but it is still very difficult to escape from the cycle of servitude (Ray and Qayum 2009). Caste-derived notions of symbolic pollution also remain. Such notions also help to signal class in other cultures such as Sweden (Ulver-Sneistrup 2008), but they are by no means as strongly entrenched as in India.

There are also cultural differences in regard to the role of luxury in standing out versus fitting in. Although luxury consumption is commonly thought of as a means of standing out from others, in some cultures it can be more a matter of fitting in. Chadha and Husband (2006) report a study of women in their twenties living in Tokyo. An overwhelming 94 percent claimed to own at least one Louis Vuitton item. Ninety-two percent said they owned a Gucci item. Prada came in at 57 percent and 
Chanel at 51 percent. When this many consumers own luxury brands, the owners are fitting in rather than standing out. In fact, these women would stand out by not owning such items. Independent versus interdependent cultures and individuals are likely to differ in their inclination toward standing out versus fitting in.

Both of these goals relate to processes of social comparison (Festinger 1954). The difference is that one is trying to match their peers (what Leibenstein (1950) called the bandwagon effect), while the other is trying to exceed their peers (what Leibenstein called the Veblen effect or the Snob effect, depending on whether the medium in which they seek to exceed them is financial or in terms of taste or expertise). But even among those pursuing the bandwagon effect by consuming popular goods, there is an assumption that there is a wisdom of crowds such that not following them is either foolish or uncool (Belk et al. 2010). One difference in a digital age is that information on fashion trends travels faster and farther. Rather than taking years for a fashion to go from the "center" (that is, large global cities) to the "periphery," it may now take only weeks or days. In addition, the distinction between core and periphery may be weakening or disintegrating. At this point in time, for example, China and India are both ahead of countries in North America and Europe in terms of using digital payments via smartphones (Joshi 2017; The Economist 2017).

The global spread of materialism should also not be taken as occurring in a uniform fashion or with a uniform understanding of the notion of materialism. In China, for example, differing cultural values and related norms such as family face, Confucianism and guanxi all help shape materialism and its expression in luxury goods consumption (Sun et al. 2017; Sun et al. 2014; Wong and Ahuvia 1998). What is more universal than the values and norms affecting the notion of materialism is its expression in the consumption of luxury goods and the escalation of consumption patterns. Ger and Belk (1999) also find that despite a near universal condemnation of materialism in the abstract, materialism is nevertheless endorsed through such expenditures. The differences are more apt to lie in making these behaviors appear to conform to specific cultural values. This is done through the different explanations offered for why "our" materialistic consumption practices are not really materialistic at all, but are instead expressions of these specific cultural values (for example, enhancing the well-being of family and children, expressing cultivated tastes, achieving happiness that is deserved because of past deprivation).

\section{ARE WE LIVING IN A POST-MATERIAL AGE?}

Ronald Inglehart $(1981 ; 1990)$ maintains that with the achievement of societal affluence in which most consumers' basic needs and desires are satisfied, we enter a post-material age in which having achieved our lower order needs we turn to higher order needs such as self-actualization and achieving a peaceful world. However, the evidence in favor of this contention is equivocal and Inglehart's conceptualization of materialism differs from commonly accepted definitions in consumer research such as those of Belk (1985), Kasser (2002), and Richins and Dawson (1992), each 
of which involves a belief of the importance of possessions in life. Inglehart instead measures materialism and "post-materialism" in terms of shifts in values such as desire for security, self-expression, and freedom (Inglehart and Abramson 1999). In this chapter the focus is on materialism as belief in the importance of possessions in life. If there were decline in materialism, it would be significant in that researchers (for example, Ahuvia 2008; Belk 1985; Burroughs and Rindfleisch 2002; Kasser 2002; Richins and Dawson 1992; Wright and Larsen 1993) document a negative relationship between materialism and feelings of happiness and well-being. But the evidence suggests that instead of decreasing, the incidence of materialism in the world is increasing and spreading (Khalid and Qadeer 2017). Ger and Belk (1996) found that materialism is more likely to increase within cultures where there is greater social mobility; it seems that when status is more in flux that people are more inclined to demonstrate their status through visible materialistic consumption.

It should be acknowledged that there is a counter argument with some evidence suggesting that materialism can lead to luxury purchases that improve positive moods and increase reports of feelings of well-being (Hudder and Pandelaere 2012). However, as Khalid and Qadeer (2017) demonstrate, these effects are short-lived results of the temporary ego and mood boost that luxury consumption may provide. The hope for a wonderful happy feeling of success in buying luxury brands is fostered by advertising portraying such results (Cleveland et al. 2017). This helps both materialism (the belief that possessions bring happiness) and luxury consumption spread globally as global affluence and access to luxury brands, or at least counterfeit luxury brands, spreads (Trinh and Phau 2011). Nevertheless, as discussed above, the rise of digital dematerialization, experiential consumption, and access-based consumption provide some hope for a less materialistic society in the future.

Another global force that affects attitudes toward materialism and concern with status is the growing disparity between haves and have-nots of the world (Ceci and Papierno 2005). Not only do materialism and consumer desire affect the consumption of luxury goods and services, the conspicuous consumption of luxury also affects consumer materialism and desire. This occurs in large part due to the mechanism of envy. Envy is a matter of social comparison. Festinger's (1954) theory of social comparison suggests that we compare ourselves to those slightly above or below us in terms of wealth. However, it seems that in an age of global communications, digital media and instant celebrities, we have now come to compare ourselves even to the super-rich and to aspire to emulate them (Jiang et al. 2014). This can have several possible results, depending on the feasibility of emulating the luxury consumption of these elites. One possibility is "benign envy" and positive motivation to work harder, earn more, consume more luxuriously, and feel deserving and justified in doing so (Belk 2008; 2011a; Van de Ven et al. 2009; 2011). A second possibility is a more negative form of envy in which less affluent consumers feel alienated and socially excluded (Jiang et al. 2014). A third possibility is that even though average consumers may feel frustrated in not being able to "keep up with the Joneses" (Matt 2003: 42; Stearns 1999), they do not want to give up on the dream and make do with pseudo-luxury, counterfeits, or cheaper versions or items (for example, sunglasses, 
wallets) with luxury brand labels. And a further possibility is that when the gap between haves and have-nots grows too large and the affluent flaunt their privileged consumption practices too blatantly, the result will be "malicious envy" which entails a desire to harm the privileged. This has been found to even lead to "money burning" in which those who are maliciously envious will sacrifice their own well-being in order to cause misfortune among those whom they envy (Zizzo 2003; Zizzo and Oswald 2001). The most extreme outcome is all-out class warfare.

It does not usually come to this, however. This is both because the rich may temper their consumption in bad economic times when aspirations of the poor are dashed and because of the move toward more inconspicuous luxury consumption that is primarily visible to those in a similar wealth stratum, but invisible or unintelligible to others (Eckhardt et al. 2015). It is also possible that the wealthy use other envy-deflecting mechanisms such as denial ("It's really nothing"), the sop (token sharing to deflect others' envy - the term comes from dipping bread in gravy), and true sharing (for example, lavish community feasts) (Foster 1969; Gell 1986). Still, as we move toward larger scale and more anonymous societies, the general move appears to be from avoiding others' envy to provoking it (Schoeck 1969; Ulanov and Ulanov 2008).

\section{FURTHER FORMS OF STATUS IN A DEMATERIALIZED WORLD}

We have considered some of the adaptations to dematerialization in such phenomena as time aristocracies, the experience economy, the sharing economy, and inflating social media profiles. But there are further changes in the nature of status-seeking within contemporary realms of consumption. As noted above, Bourdieu (1984) suggests that as material consumption has been democratized or at least made more accessible to those with money, a key way in which class is reproduced is through non-material cultural capital. Cultural capital consists of knowledge and tastes that are generally acquired and passed along through habitus gained from parents and friends of a similar social class, but also through education. It might include how we talk, our manners, how we dress, what we know of art and music, political attitudes and so forth, although the particulars of this knowledge differ across cultures (Holt 1998). But with the internet and search engines, at least a portion of such knowledge can be gained with a few flicks of the finger (Eckhardt et al. 2015). Bourdieu (1984) also formulated economic and social capital forms that have some potential to be converted into cultural capital. For example, economic capital might be a route to cultural capital by acquiring a fine education. Having the right friends (social capital) may also be a way to learn the tastes of a higher social class.

But this too changes in a digital age. We can acquire and display our social capital through "collecting" friends, likes, and comments on social media like Facebook. We can also deploy and display our cultural capital by having a blog or YouTube channel with many followers or subscribers. And we can gain social capital as well as display 
cultural capital by creating an interesting online persona. Hamelink (2000) and van Dijk (2005) suggest that in addition to these principal types of capital, in a digital age we must add information capital. This involves access to information through owning or having access to digital devices and internet connections as well as having the expertise to be able to successfully navigate the internet in order to acquire information (Tenhunen 2018). Those who have programming skills have an advantage today (Paino and Renzulli 2012). Not only does information capital contribute to cultural capital through knowledge of class-based tastes, it also can contribute to social capital via social media contacts and contribute to economic capital through access to job information, for example (Ignatow and Robinson 2017). Such digital information capital is unequally distributed not only among individuals, but among nations as well (Park 2017). Knowledge is power in an information age, just as knowledge of forbidden pop Western music was once a source of power and prestige in communist Eastern Europe (Belk 1997).

At the same time, we must recognize that there is a growing awareness of the downsides and dangers of the digital age. Fear of Missing Out (FOMO) seems to drive many people to check their digital devices incessantly (Belk 2013). It would seem that for many, digital access, digital devices, and digital applications have gone from luxuries to necessities to addictions. There is growing evidence that use of the internet, digital devices, online gaming, online gambling, social media, and certain apps can all be clinically addictive (for example, Cotte and Latour 2009; Cover 2004; Yoo et al. 2004; Young 2009). Even without clinical addiction there is increasing consensus that over-use of the digital causes stress and can become a form of compulsive consumption in our daily lives such that we may need a "digital diet" or "digital detox" (for example, Brabazon 2012; Lim et al. 2013; Löcktefeld et al. 2013; Montag et al. 2016). Adults are not only concerned for themselves, but for their children and even infants who also seem to be addicted to these digital distractions (Bavelier et al. 2010; Young 2009). In the movement of digital devices from luxuries to gateways to problematic addictions, compulsions, and stresses, offerings of digital detox to remove us from our digital devices have become a luxury in some places (for example, Amsberg and Huber 2015; Brabazon 2012; Lim et al. 2013). This movement may also help to explain the surge in retro-consumption offerings taking consumers back to a pre-digital era (for example, Brown and Sherry 2003; Brown et al. 2003).

In an interesting and perhaps prescient piece of science fiction, Frederick Pohl (1954/1983) imagined a future society in which robots have taken over production, energy is cheap, and too many consumer goods are produced to be readily consumed. As a result, social class consumption is flipped on its head and the "poor" are forced to live in mansions with dozens of rooms, own stables of multiple vehicles, employ many robots, and eat copiously. The "rich" on the other hand are allowed to live simply without all these burdens of ownership and over-consumption. Property crime is non-existent because everyone has more than they need and no one wants to be encumbered by still more possessions. Whether or not such a scenario is likely, it raises the possibility that Ludwig Mies van der Rohe's ethos that "less is more" 
(derived from an 1855 Robert Browning poem) might have merit. More things and more expensive things are not always best. We display some of this ethos in voluntary simplicity, downsizing, and the tiny home movement. There have also been times and places in which this ethos has had greater salience. For example, during the first Arab oil embargo in the early 1970s, owning a large gas-guzzling car became a stigma, while owning a small car became a status symbol.

Having a tiny home also necessitates having few possessions. Together with a commitment to the sharing economy and replacement of certain tangible possessions with digital equivalents, some people are intentionally living with less. Still, when it is cast this way - that we must give up something that brings pleasure and distinction, it is unlikely that simplicity movements will ever become mainstream (Belk 2011b). Pohl's (1954/1983) story turns on seeking that which is forbidden or in short supply - in this case the freedom from the burden of possessions in a society of excessive abundance. "Rich" consumers in the story gain power and control of their lives by living simply.

\section{CONCLUSION}

While it seems on its face that materialism and status-seeking through consumption should decline or even disappear in a digital and sharing age of dematerialization, this chapter makes the case that this is far from being the reality. And while some forms of status-seeking now involve intangible knowledge and skills, this has been the case long before life became digital. As with many innovations, the non-material world of digital devices brings both pleasures and perils. The same was true of the automobile, for example, which brought convenience, new opportunities, and new lifestyles but also road carnage, pollution, the hollowing out of the inner city, and damage to the natural environment. Humans adapt and will continue to adapt to our material and non-material circumstances. While the way we express and seek status may differ, we continue to seek these things through acquiring scarce and admired resources that connote power, prestige, and control over our lives. Paradoxically, they may not always bring pleasure, as we have seen with the burdens of ownership, digital addiction and compulsion, and the shortages of time that accompany attending our digital devices and earning money in pursuit of more. There is already some evidence that we are now using our money to acquire more time rather than more things. We outsource care of our homes, possessions, and bodies. We seek experiences rather than more stuff. And we buy objects like Roomba robot vacuum cleaners and digital personal assistants like Apple's Siri, Amazon's Echo (Alexa), Google Home, and Microsoft Cortana. It may not be long before robots care for our elderly and children, transport us in driverless cars and pilotless planes, and educate us in teacherless schools.

The prospect of robots in homes, factories, shops, and offices is an emerging digital development that should become an important area of research (Belk 2016; 2017a; 2018; Goudey and Bonnin 2016; Hoffman and Novak 2018). Together with 
AI, some see the advance of robots progressing to a point called the singularity when their intelligence equals ours and then quickly surpasses it as intelligent robots reprogram themselves and grow exponentially superior. We already live in an age of "weak AI." Every Google or Baidu search, Amazon or Alibaba query, and Uber or Didi request involves AI, but AI that has been programmed by human beings. When we have general or strong AI platforms, our computers and devices will be able to improvise and do things beyond their basic programming. Together with super-intelligent computers, this is when experts warn that we may no longer be safe from machines (Shukman 2015). Elon Musk says it will be "like summoning the demon" (Marcus 2014). Stephen Hawking warned that it could "outsmart us all" and "spell the end of the human race" (Dingman 2014). While not everyone agrees with these dire warnings (for example, Floridi 2016; Lewis 2015), Bill Gates insists that it is something we need to be worried about now rather than when it is too late to do anything about it (Rawlinson 2015).

Research issues abound in these areas including how we respond to various types of robots (humanoid, animal, voice-interactive), the process of anthropomorphism, the degree of trust robots can generate and how, and ultimately the degree to which we may be willing to attribute personhood to these devices. The disaster scenarios above also prompt us to think about issues of robot morality (Calverly 2011; Gips 1995/2011; Grau 2011). How do we make robots moral and friendly helpers rather than potential enemies? Further moral issues emerge with sex robots (Sullins 2012; Whitby 2012) and military robots that can kill (Hellström 2013; Singer 2009).

One of the responses proposed to the possibility of a robot takeover is cyborg enhancement of human capabilities in order to keep up. The consumer research that focuses on the cyborg rightly notes that it is a liminal figure between the body and the machine, the past and the future, and here and not-here (Buchanan-Oliver and Cruz 2011), as well as between the communal and individual self and between the religious and secular self (Hemetsberger 2005). Based on a netnographic study, Bhattacharyya and Kedzior (2012) find three threats posed by cyborg technology: humans giving up control to technology; humans using cyborg technology to control other humans; and humans losing the essence of being human by becoming cyborgs. At the same time, they also find three discourses facilitating acceptance of technologically modified bodies: overcoming the flaws of nature; following technological evolution; and pursuing the potential to become godlike. But if cyborg modifications through drugs, electronic prostheses, and neural implants are the way to keep up with future super-intelligent robots and AI emerges, there is another luxury concern. These modifications may only be affordable by the rich. This could have two effects. One is that there will be a two-tier society of the haves and have-nots with regard to enhancements. The other is that if such modifications make the difference in being valued by super-strong and super-smart it will not be the haves versus the have-nots in terms of status and opportunities (a theme played out in films like Gattica and Elysium), but rather the valuable and living versus the valueless and non-living (a plot played out in films like Ex Machina). 
The last concern leads to considerations of transhumanism. Some ardently believe that we will soon have the option to become transhuman beings capable of living indefinitely. And transhumans are seen as a waypoint in creating a new species truly posthuman beings. Hayles (2005: 1) describes this trajectory as the move from "Homo sapiens to Robo sapiens, from humans to intelligent machines." As Bostrom (2011: 55) characterizes it:

Transhumanism is a loosely defined movement that has developed gradually over the past two decades and can be viewed as an outgrowth of secular humanism and the Enlightenment. It holds that current human nature is improvable through the use of applied science and other rational methods, which make it possible to increase human health span, extend our intellectual and physical capacities, and give us increased control over our own mental states and moods.

This is a perspective that has begun to interest consumer researchers (Buchanan-Oliver and Cruz 2011; Giesler 2004; Venkatesh et al. 2002). It involves the search for what has been called techno-utopia (Braidotti 1996). Exactly what such a utopia would be like, how it might be achieved, and what its impact would be are all open questions. With parallels to Christian Eschatology, Geraci (2010) calls transhumanism "Apocalyptic AI." But in this case the beliefs are in science rather than God. It is a provocative and well-argued thesis that is in need of further research. Again we can envision a society of long-lived transhumanists who can afford the means of pursuing immortality (for example, through uploading consciousness into computers or robots) and those who cannot afford to do so.

As we have seen in the past, digital technological changes are not distributed evenly across societal segments and parts of the world. However, we have seen that in some cases digital devices and internet access have been able to leapfrog the stages of development that they went through in the more affluent world (Belk 1999; Joshi 2017). Thus, with mobile phones, remote places in India, China, and Africa have not had to wait for telephone lines. The same accelerated spread is true of television, fashions, music, and information. Cultural differences remain, but the world is becoming flatter in terms of access to at least some of these resources (Friedman 2005). Processes of seeking prestigious distinction, provoking envy, and pursuing power and control over our lives and over others are not likely to disappear anytime soon. Whether material or non-material, possessions or experiences, products or services, living large or living small, some things seem never to change. There are pockets of people who resist these things and their pursuit may temporarily disappear in times of war or natural disasters when we seem to learn that human relationships matter more. But in the end, we remain materialistic, even in a non-material world.

\section{REFERENCES}

Ahuvia, Aaron (2008), 'If Money Doesn't Make Us Happy, Why Do We Act as if it Does?', Journal of Economic Psychology, 29 (4), 491-507. 
Amsberg, Sanderyn and Ariel Huber (2015), 'Village for Sale', Perspective, accessed on August 4, 2018, at https://repository.tudelft.nl/islandora/object/uuid:982b1fa7-537b-4062 -b8fe-480f0571e333/datastream/OBJ.

Arnold, Jeanne, Anthony Graesch, Enzo Ragazzini, and Elinor Ochs (2012), Life at Home in the Twenty-First Century: 35 Families Open Their Doors, Los Angeles, CA, USA: Cotsen Institute of Archaeology Press.

Bardhi, Fleura and Giana Eckhardt (2012), 'Access Based Consumption: The Case of Car Sharing', Journal of Consumer Research, 39 (4), 381-398.

Bardhi, Fleura and Giana Eckhardt (2015), 'The Sharing Economy Isn't About Sharing at All', Harvard Business Review, accessed on January 28, 2017, at https://hbr.org/2015/01/the -sharing-economy-isnt-about-sharing-at-all.

Bavelier, Daphne, Shawn Green, and Mathew Dye (2010), 'Children, Wired: For Better or Worse', Neuron, 67 (5), 692-701.

Belk, Russell (1985), 'Materialism: Trait Aspects of Living in the Material World', Journal of Consumer Research, 12 (3), December, 265-280.

Belk, Russell (1988), 'Possessions and the Extended Self', Journal of Consumer Research, 15 (2), 139-168.

Belk, Russell (1997), 'Romanian Consumer Desires and Feelings of Deservingness', in Lavinia Stan (ed.), Romania in Transition, Aldershot, UK: Dartmouth Press, pp. 191-208.

Belk, Russell (1999), 'Leaping Luxuries and Transitional Consumers', in Rajiv Batra (ed.), Marketing Issues in Transitional Economies, Norwell, MA, USA: Kluwer, pp. 39-54.

Belk, Russell (2008), 'Envy and Marketing', in Richard Smith (ed.), Envy: Theory and Research, Oxford, UK: Oxford University Press, pp. 211-226.

Belk, Russell (2010), 'Sharing', Journal of Consumer Research, 36 (5), February, 715-734.

Belk, Russell (2011a), 'Benign Envy', Academy of Marketing Science Review, 1 (December), 117-134.

Belk, Russell (2011b), 'Philosophies for Less Consuming Societies', in Karin Ekström and Kay Glans (eds), Beyond the Consumption Bubble, London, UK: Routledge, pp. 205-220.

Belk, Russell (2013), 'Extended Self in a Digital World', Journal of Consumer Research, 40 (October), 477-500.

Belk, Russell (2014a), 'Sharing versus Pseudo-Sharing in Web 2.0', The Anthropologist, 18 (1), 7-23.

Belk, Russell (2014b), 'You are What You can Access: Sharing and Collaborative Consumption Online', Journal of Business Research, 67 (8), 1595-1600.

Belk, Russell (2015), 'Post-Ownership Sustainability', in Karin Ekström (ed.), Waste Management and Sustainable Consumption with The Problem of Post-Consumer Waste, Abingdon, UK: Routledge, pp. 199-213.

Belk, Russell (2016), 'Understanding the Robot: Comments on Goudey and Bonnin', Recherche et Applications en Marketing, 31 (4), 89-97.

Belk, Russell (2017a), 'Consumers in an Age of Autonomous and Semi-Autonomous Machines', in John Sherry, Jr. and Eileen Fischer (eds), Currents in Consumer Culture Theory, London, UK: Routledge, pp. 5-32.

Belk, Russell (2017b), 'Sharing, Materialism, and Design for Sustainability', in Jonathan Chapman (ed.), Routledge Handbook of Sustainable Product Design, London, UK: Routledge, pp. 160-172.

Belk, Russell (2017c), 'Sharing without Caring', Cambridge Journal of Regions, Economy, and Society, 10 (2), 249-261.

Belk, Russell (2018), 'Robots, Cyborgs, and Consumption', in Alan Lewis (ed.), Cambridge Handbook of Psychology and Economic Behaviour, Cambridge: Cambridge University Press, pp. 741-758. 
Belk, Russell, Kelly Tian, and Heli Paavola (2010), 'Consuming Cool: Behind the Unemotional Mask', in Russell Belk (ed.), Research in Consumer Behavior, Bingley, UK: Emerald Publishing, pp. 183-208.

Berger, Jonathan and Morgan Ward (2010), 'Subtle Signals of Inconspicuous Consumption', Journal of Consumer Research, 37 (4), 555-569.

Bhattacharyya, Arundhati and Richard Kedzior (2012), 'Consuming the Cyborg', Advances in Consumer Research, 40, 960-961.

Bode, Matthias and Dorthe Kristensen (2016), 'The Digital Doppelgänger Within: A Study on Self-Tracking and the Quantified Self Movement', in Robin Canniford and Domen Bajde (eds), Assembling Consumption: Researching Actors, Networks and Markets, London, UK: Routledge, pp. 119-134.

Bostrom, Nick (2011), 'In Defense of Posthuman Dignity', in Gregory Hansell and William

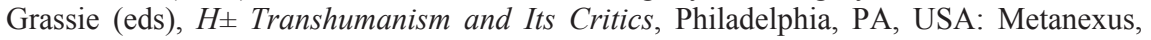
pp. 55-66.

Bourdieu, Pierre (1984), Distinction: A Social Critique of the Judgment of Taste, London, UK: Routledge and Kegan Paul.

Brabazon, Tara (2012), 'Time for Digital Detox? From Information Obesity to Digital Dieting', Fast Capitalism, 9 (1), accessed on August 4, 2018, at https://www.uta.edu/huma/ agger/fastcapitalism/9 1/brabazon9_1.html.

Braidotti, Rosi (1996), 'Signs of Wonder and Traces of Doubt: On Teratology and Embodied Differences', in Nina Lykke and Rosi Braidotti (eds), Between Monsters, Goddesses and Cyborgs: Feminist Confrontations with Science, Medicine and Cyberspace, London: Zed Books, pp. 134-152.

Brown, Stephen, Robert Kozinets, and John F. Sherry, Jr. (2003), 'Teaching Old Brands New Tricks: Retrobranding and the Revival of Brand Meaning', Journal of Marketing, 67 (July), 19-33.

Brown, Stephen and John F. Sherry, Jr. (eds) (2003), Time, Space and the Market: Retroscapes Rising, Armonk, NY, USA: M.E. Sharpe.

Buchanan-Oliver, Margo and Angela Cruz (2011), 'Discourses of Technology Consumption: Ambivalence, Fear, and Liminality', Advances in Consumer Research, 39, 287-291.

Burroughs, James and Aric Rindfleisch (2002), 'Materialism and Well-being: A Conflicting Values Perspective', Journal of Consumer Research, 29 (3), 348-370.

Calverley, David (2011), 'Legal Rights for Machines: Some Fundamental Concepts', in Michael Anderson and Susan Anderson (eds), Machine Ethics, Cambridge: Cambridge University Press, pp. 213-227.

Ceci, Stephen and Paul Papierno (2005), 'The Rhetoric and Reality of Gap Closing: When the "Have-Nots" Gain but the "Haves" Gain Even More', American Psychologist, 60 (2), 149-160.

Chadha, Radha and Paul Husband (2006), The Cult of the Luxury Brand: Inside Asia's Love Affair with Luxury, London, UK: Nicholas Brealey.

Chen, Vivienne Yu (2009), 'Possession and Access: Consumer Desires and Value Perception Regarding Contemporary Art Collecting and Exhibit Visits', Journal of Consumer Research, 35 (April), 925-940.

Cleveland, Mark, Michel Laroche, and Nicolas Papadoulus (2017), 'Global Consumer Culture and Local Identity as Drivers of Materialism: An International Study of Convergence and Divergence', in Colin Campbell and Junzhou (Jonathan) Ma (eds), Looking Forward, Looking Back: Drawing on the Past to Shape the Future of Marketing: Proceedings of the 2013 World Marketing Congress, Heidelberg, Germany: Springer, pp. 479-485.

Cotte, June and Kathryn Latour (2009), 'Blackjack in the Kitchen: Understanding Online Versus Casino Gambling', Journal of Consumer Research, 35 (5), 742-758. 
Cover, Rob (2004), 'Digital Addiction: The Cultural Production of Online and Video Game Junkies', Media International Australia, accessed on November 1, 2017, at http://journals .sagepub.com/doi/abs/10.1177/1329878X0411300113.

Currid-Halkett, Elizabeth (2017), The Sum of Small Things: A Theory of the Aspirational Class, Princeton, NJ, USA: Princeton University Press.

Daloz, Jean-Pascal (2013), Rethinking Social Distinction, Basingstoke, UK: Palgrave Macmillan.

Danziger, Pamela (2005), Let Them Eat Cake: Marketing Luxury to the Masses - as well as the Classes, Chicago, IL, USA: Dearborn Trade Publishing.

Dickey, Sara (2016), Living Class in Urban India, New Brunswick, NJ, USA: Rutgers University Press.

Dingman, Shane (2014), 'Even Stephen Hawking Fears the Rise of Machines', Globe and Mail, December 2, accessed on August 4, 2018, at http://www.theglobeandmail.com/ technology/even-stephen-hawking-fears-the-rise-of-machines/article21888416/.

Durgee, Jeffrey and Gina O'Connor (1995), 'An Exploration into Renting in Consumption Behavior', Psychology and Marketing, 12 (2), 89-104.

Eckhardt, Giana and Fleura Bardhi (2016), 'The Relationship Between Access Practices and Economic Systems', Journal of the Association for Consumer Research, 1 (2), 210-225.

Eckhardt, Giana, Russell Belk, and Jonathan Wilson (2015), 'The Rise of Inconspicuous Consumption', Journal of Marketing Management, 31 (7-8), 807-826.

Festinger, Leon (1954), 'A Theory of Social Comparison Processes', Human Relations, 7, $117-140$.

Floridi, Luciano (2016), 'Humans Have Nothing to Fear from Intelligent Machines', Financial Times, January 25, accessed on August 4, 2018, at https://next.ft.com/content/9a6b6536 -c372-11e5-808f-8231cd71622e.

Foster, George (1969), 'Peasant Society and the Image of Limited Good', American Anthropologist, 67, 293-315.

Friedman, Thomas (2005), The World is Flat: A Brief History of the Twenty-First Century, New York, NY, USA: Farrar, Strauss and Giroux.

Furubotn, E.G. and S. Pejovich (1972), 'Property Rights and Economic Theory: A Survey of Recent Literature', Journal of Economic Literature, 10 (4), 1137-1162.

Gell, Alfred (1986), 'Newcomers to the World of Goods: Consumption Among the Muria Gond', in Arjun Appadurai (ed.), The Social Life of Things, Cambridge, UK: Cambridge University Press, pp. 110-138.

Ger, Güliz and Russell Belk (1996), 'Cross-Cultural Differences in Materialism', Journal of Economic Psychology, 17 (1), February, 55-78.

Ger, Güliz and Russell Belk (1999), 'Accounting for Materialism in Four Cultures', Journal of Material Culture, 4 (July), 183-204.

Geraci, Robert (2010), Apocalyptic AI: Visions of Heaven in Robotics, Artificial Intelligence, and Virtual Reality, Oxford, UK: Oxford University Press.

Gibson, Chris, Natasha Klocker, Erin Borger, and Sophie-May Kerr (2018), 'Malleable Homes and Mutual Possessions: Caring and Sharing in Extended Family Households as a Resource for Survival', in Anthony Ince and Sarah Marie-Hall (eds), Sharing Economies in Times of Crisis: Practices, Politics and Possibilities, London, UK: Routledge, pp. 35-49.

Giesler, Markus (2004), 'Consuming Cyborgs: Posthuman Consumer Culture and its Impact on the Conduct of Marketing', Advances in Consumer Research, 31, 401-402.

Giesler, Markus (2006), 'Consumer Gift System: Netnographic Insights from Napster', Journal of Consumer Research, 33 (September), 283-290.

Gips, James (1995/2011), 'Towards the Ethical Robot', in Michael Anderson and Susan Anderson (eds), Machine Ethics, Cambridge: Cambridge University Press, pp. 244-253. 
Goudey, Alain and Gael Bonnin (2016), 'Must Smart Objects Look Human? Study of the Impact of Anthropomorphism on the Acceptance of Companion Robots', Recherche et Applications en Marketing, 31 (2), 3-22.

Grau, Christopher (2011), 'There is no "I" in "Robot": Robots and Utilitarianism', in Michael Anderson and Susan Anderson (eds), Machine Ethics, Cambridge: Cambridge University Press, pp. 451-463.

Hamelink, Cees (2000), The Ethics of Cyberspace, London, UK: Sage.

Hayles, N. Katherine (2005), My Mother Was a Computer: Digital Subjects and Literary Texts, Chicago, IL, USA: University of Chicago Press.

Hellström, Thomas (2013), 'On the Moral Responsibility of Military Robots', Ethics, Information, Technology, 15, 99-107.

Hemetsberger, Andrea (2005), 'Creative Cyborgs: How Consumers Use the Internet for Self Realization', Advances in Consumer Research, 32, 653-660.

Hochschild, Arlie (2012), The Outsourced Self: Intimate Life in Market Times, New York, NY, USA: Metropolitan Books.

Hoffman, Donna and Thomas Novak (2018), 'Consumer and Object Experience in the Internet of Things: An Assemblage Theory Approach', Journal of Consumer Research, 44 (6), $1178-1204$.

Holt, Douglas (1998), 'Does Cultural Capital Structure American Consumption?', Journal of Consumer Research, 25 (1), 1-25.

Hudder, Liselot and Mario Pandelaere (2012), 'The Silver Lining of Materialism: The Impact of Luxury Consumption on Subjective Well-Being', Journal of Happiness Studies, 13 (3), 411-437.

Ignatow, Gabe and Laura Robinson (2017), 'Pierre Bourdieu: Theorizing the Digital', Information, Communication and Society, 20 (7), 950-956.

Inglehart, Ronald (1981), 'Post-Materialism in an Environment of Insecurity', American Political Science Review, 75 (December), 880-900.

Inglehart, Ronald (1990), Culture Shift in Advanced Industrial Society, Princeton, NJ, USA: Princeton University Press.

Inglehart, Ronald and Paul Abramson (1999), 'Measuring Postmaterialism', American Political Science Review, 93 (3), 665-677.

Jiang, Ming, Ming-Guo Gao, Ren Huang, C. Nathan DeWall, and Xinyue Zhou (2014), 'The Devil Wears Prada: Advertisements of Luxury Brands Evoke Feelings of Social Exclusion', Asian Journal of Social Psychology, 17 (4), 245-254.

Joshi, Amit (2017), 'Digital Economy: The Great Indian Leapfrog', Forbes India, accessed on November 22, 2017, at http://www.forbesindia.com/article/imd-business-school/digital -economy-the-great-indian-leapfrog/48705/1.

Kasser, Timothy (2002), The High Price of Materialism, Cambridge, MA, USA: MIT Press.

Khalid, Afia and Faisal Qadeer (2017), Rising Consumer Materialism: A Threat to Consumer Happiness, London, UK: Routledge.

Knox, George and Jehoshua Eliashberg (2008), 'The Consumer's Rent vs. Buy Decision in the Rentailer', International Journal of Research in Marketing, 26 (2), 125-135.

Kumar, Amit, Andrew Killingsworth, and Thomas Gilovich (2014), 'Anticipatory Consumption of Experiential and Material Purchases', Psychological Science, 25 (10), 1924-1931.

Le Bel, Jordan (2005), 'Sensory, Snob, and Sex Appeals in Wine Advertising', International Journal of Wine Marketing, 17 (3), 67-77.

Lehdonvirta, Vili and Edward Castronova (2014), Virtual Economies: Design and Analysis, Cambridge, MA, USA: MIT Press.

Leibenstein, Harold (1950), 'Bandwagon, Snob and Veblen Effects in the Theory of Consumer Demand', Quarterly Journal of Economics, 64 (2), 183-207.

Lewis, Abbie and Miguel Moital (2016), 'Young Professionals' Conspicuous Consumption of Clothing', Journal of Fashion Marketing and Management, 20 (2), 138-156. 
Lewis, Colin (2015), 'Out of Control AI will not Kill Us, Believes Microsoft Research Chief', $B B C$ News, January 28, accessed on August 4, 2018, at http://www.bbc.com/news/ technology-31023741.

Lim, Soon-Taik, Dong-Gun Lee, and Sang-Joon Lee (2013), 'A Study on the Factors Affecting Satisfaction of Smartphone Users', Journal of Digital Convergence, 11 (1), 129-138.

Lin, Yi-Chieh (2011), Fake Stuff: China and the Rise of Counterfeit Goods, London, UK: Routledge.

Löcktefeld, Markus, Matthias Bömer, and Lyobomir Ganev (2013), 'AppDetox: Helping Users with Mobile App Addiction', Proceedings of the 12th International Conference on Mobile and Ubiquitous Multimedia, accessed on August 6, 2018, at https://dl.acm.org/ citation.cfm?id=2541870.

Lu, Pierre Xiao (2008), Elite China: Luxury Consumer Behavior in China, Singapore: Wiley. Magaudda, Paulo (2011), 'When Materiality "Bites Back": Digital Music Consumption in the Age of Dematerialization', Journal of Consumer Culture, 11 (1), 16-36.

Magaudda, Paulo (2012), 'What Happens to Materiality in Digital Virtual Consumption?', in Mike Molesworth and Janice Denegri-Knott (eds), Digital Virtual Consumption, London, UK: Routledge, pp. 111-126.

Marcus, Gary (2014), 'Artificial Intelligence Isn't a Threat - Yet', Wall Street Journal, December 11, accessed on August 4, 2018, at http://www.wsj.com/articles/artificial -intelligence-isnt-a-threatyet-1418328453.

Mardon, Rebecca and Russell Belk (2018), 'Materialising Digital Collecting: An Extended View of Digital Materiality', Marketing Theory, 18 (4), 543-570.

Mason, Roger (1981), Conspicuous Consumption, New York, NY, USA: St. Martin's Press.

Mason, Roger (1998), The Economics of Conspicuous Consumption: Theory and Thought Since 1700, Cheltenham, UK and Northampton, MA, USA: Edward Elgar Publishing.

Matt, Susan (2003), Keeping Up with the Joneses: Envy in American Consumer Society, 1890-1930, Philadelphia, PA, USA: University of Pennsylvania Press.

Moeller, Sabine and Kristina Wittkowski (2010), 'The Burdens of Ownership: Reasons for Preferring Renting', Managing Service Quality, 20 (2), 176-190.

Montag, Christian, Peter Walla, and Monika Koller (2016), 'Carpe Diem Instead of Losing Your Social Mind: Beyond Digital Addiction and Why We all Suffer from Digital Overuse', Cogent Psychology, 3 (1), accessed on August 4, 2018, at http://www.tandfonline .com/doi/abs/10.1080/23311908.2016.1157281.

Paino, Maria and Linda Renzulli (2012), 'Digital Dimensions of Cultural Capital: The (In) Visible Advantages for Students who Exhibit Computer Skills', Sociology of Education, 86 (2), 124-138.

Pakulski, Jan and Malcolm Waters (1996), The Death of Class, London, UK: Sage.

Palfrey, John and Urs Gasser (2008), Born Digital: Understanding the First Generation of Digital Natives, New York, NY, USA: Basic Books.

Park, Sora (2017), Digital Capital, London, UK: Palgrave Macmillan.

Pedersen, Esben and Sarah Netter (2015), 'Collaborative Consumption Business Model Opportunities and Barriers for Fashion Libraries', Journal of Fashion Marketing and Management, 19 (3), 258-273.

Pine, B. Joseph II and James Gilmore (1999), The Experience Economy: Work Is Theatre and Every Business is a Stage, Boston, MA, USA: Harvard Business School Press.

Pohl, Frederick (1954/1983), Midas World, New York, NY, USA: St. Martin's Press.

Potter, Andrew (2010), The Authenticity Hoax: How We Get Lost Finding Ourselves, Toronto, Canada: McClelland and Stewart.

Putnam, Robert D. (2000), Bowling Alone: The Collapse and Revival of American Community, New York, NY, USA: Simon \& Schuster. 
Quintão, Ronan, Russell Belk, and Elaine Brito (2017), 'Connoisseurship Consumption Community and its Dynamics', Revista Brasileira de Gestão de Negócios (Journal of Business Management), 19 (63), 48-64.

Rawlinson, Kevin (2015), 'Microsoft's Bill Gates Insists AI is a Threat', BBC News, January 29, accessed on August 4, 2018, at http://www.bbc.com/news/31047780.

Ray, Raka and Seekin Qayum (2009), Cultures of Servitude: Modernity, Domesticity, and Class in India, Stanford, CA, USA: Stanford University Press.

Richins, Marsha and Scott Dawson (1992), 'A Consumer Values Orientation for Materialism and its Measurement: Scale Development and Validation', Journal of Consumer Research, 19 (3), 303-316.

Rifkin, Jeremy (2000), The Age of Access: The New Culture of Hypercapitalism Where All of Life is a Paid-for Experience, New York, NY, USA: Jeremy P. Tarcher/Putnam.

Rudmin, Floyd (2016), 'The Consumer Science of Sharing: A Discussant's Observations', Journal of the Association for Consumer Research, 1 (2), 198-209.

Schoeck, Helmut (1969), Envy: A Theory of Social Behavior, New York, NY, USA: Bantam Doubleday.

Shukman, David (2015), 'How Safe Can Artificial Intelligence Be?', BBC News, September 15, accessed on August 4, 2018, at http://www.bbc.com/news/science-environment-34249500.

Silverstein, Michael and Neil Fiske (2003), Trading Up: Why Consumers Want New Luxury Goods and How Companies Create Them, New York, NY, USA: Portfolio.

Singer, P.W. (2009), Wired for War: The Robotics Revolution and Conflict in the 21st Century, New York: Penguin.

Stearns, Peter (1999), The Battleground of Desire: The Struggle for Self-Control in Modern America, New York, NY, USA: New York University Press.

Sullins, John (2012), 'Robots, Love, and Sex: The Ethics of Building a Love Machine', IEEE Transactions on Affective Computing, 3 (4), 398-409.

Sun, Gong, Steven D’Alesandro, and Lester Johnson (2014), 'Traditional Culture, Political Ideologies, Materialism and Luxury Consumption in China', International Journal of Consumer Studies, 38 (6), 578-585.

Sun, Gong, Wangshusi Wang, Zhiming Cheng, Jie Li, and Junhua Chen (2017), 'The Intermediate Linkage Between Materialism and Luxury Consumption: Evidence from the Emerging Market of China', Social Indicators Research, 132 (1), 475-487.

Tapscott, Don (2008), Grown Up Digital: How the Net Generation is Changing Your World, New York, NY, USA: McGraw-Hill.

Tenhunen, Sirpa (2018), A Village Goes Mobile: Telephony, Mediation, and Social Change in Rural India, Oxford: Oxford University Press.

The Economist (2017), 'The Age of Appacus: In Fintech, China Shows the Way', The Economist, accessed on February 25, 2017, at https:/www.economist.com/news/finance -and-economics/21717393-advanced-technology-backward-banks-and-soaring-wealth -make-china-leader.

Thomas, Dana (2007), Deluxe: How Luxury Lost its Luster, New York, NY, USA: Penguin.

Trinh, Viet and Ian Phau (2011), 'Influence of Materialism and Life Satisfaction on Consumer Willingness to Buy Counterfeit Luxury Brands', paper presented at International Conference 'Luxury and Counterfeiting', Wesford, Geneva, June 9-10, accessed on August 4, 2018, at https://ssrn.com/abstract=1911106.

Ulanov, Ann and Barry Ulanov (2008), Cinderella and Her Sisters: The Envied and the Envying, Philadelphia, PA, USA: Westminster Press.

Ulver-Sneistrup, Sofia (2008), Status Spotting: A Consumer Cultural Exploration into Ordinary Status Consumption of 'Home' and Home Aesthetics, Lund, Sweden: Lund Business Press.

Usborne, Simon (2017), 'Just Do it: The Experience Economy and How We Turned our Backs on "Stuff"', The Guardian, May 13, accessed on August 4, 2018, at https://www 
.theguardian.com/business/2017/may/13/just-do-it-the-experience-economy-and-how-we -turned-our-backs-on-stuff.

Van Boven, Leaf and Thomas Gilovich (2003), 'To Do or to Have? That is the Question', Journal of Personality and Social Psychology, 85, 1193-1202.

Van de Ven, Niels, Marcel Zeelenberg, and Rik Pieters (2009), 'Leveling Up and Leveling Down: The Experiences of Benign and Malicious Envy', Emotion, 9 (3), 419-429.

Van de Ven, Niels, Marcel Zeelenberg, and Rik Pieters (2011), 'The Envy Premium in Product Evaluation', Journal of Consumer Research, 37 (6), 984-998.

van Dijk, Jan (2005), The Deepening Divide: Inequality in the Information Society, Thousand Oaks, CA, USA: Sage.

Veblen, Thorstein (1899/1973), The Theory of the Leisure Class, Boston, MA, USA: Houghton Mifflin.

Venkatesh, Alladi, Eminegul Karababa, and Güliz Ger (2002), 'The Emergence of the Posthuman Consumer and the Fusion of the Virtual and the Real: A Critical Analysis of Sony's Ad for Memory Stick ${ }^{\mathrm{TM}}$ ', Advances in Consumer Research, 29, 446-452.

Wang, Jeff, Xin Zhao, and Gary Bamossy (2009), 'The Sacred and the Profane in Online Gaming: A Netnographic Inquiry of Chinese Consumers', in Natalie Wood and Michael Solomon (eds), Virtual Social Identity and Consumer Behavior, Armonk, NY, USA: Society for Consumer Psychology, pp. 109-124.

Whitby, Blay (2012), 'Do You Want a Robot Lover? The Ethics of Caring Technologies', in Patrick Lin, Keith Abney, and George Bekey (eds), Robot Ethics: The Ethical and Social Implications of Robotics, Cambridge, MA: MIT Press, pp. 233-248.

Widlok, Thomas (2017), Anthropology and the Economy of Sharing, London, UK: Routledge. Wong, Nancy and Aaron Ahuvia (1998), 'Personal Taste and Family Face: Luxury Consumption in Confucian and Western Societies', Psychology and Marketing, 15 (5), 423-441.

Wright, Newell and Val Larsen (1993), 'Materialism and Life Satisfaction: A Meta-analysis', Journal of Consumer Satisfaction, Dissatisfaction, and Complaining Behavior, 6, 158-165.

Yoo, Hee Jeon, Soo Cho, Jihyun Ha, Sook Ma, Seog Kim, Jaeuk Hwang, Ain Ba, Young Sung, and In Lyoo (2004), 'Attention Deficit Hyperactivity Symptoms and Internet Addiction', Psychiatry and Clinical Neurosciences, 58 (5), 487-494.

Young, Kimberly (2009), 'Internet Addiction: The Emergence of a New Clinical Disorder', Cyber-psychology and Behavior, 1 (3), 237-244.

Zizzo, Daniel (2003), 'Money Burning and Rank Egalitarianism with Random Dictators', Economics Letters, 81, 263-266.

Zizzo, Daniel and Andrew Oswald (2001), 'Are People Willing to Pay to Reduce Others' Incomes?', Annales d'Economie et de Statistique, 63-64, 39-62. 